\title{
An analysis of the transportation planning for the 2010 Soccer World Cup in South Africa
}

\author{
C. B. Schoeman \\ School for Environmental Sciences and Development, \\ North West University (Potchefstroom Campus), South Africa
}

\begin{abstract}
South Africa will host one of the Soccer World Cups in 2010. This event will require that the present transport system be upgraded not only for the event, but also to support sustainable economic growth and development in the period post 2010 .

For the National Department of Transport (NDOT), the 2010 FIFA World Cup needs to be a success if the accelerated transport investment secured in preparation for 2010 must support and address the upgrading in the quality transport services, infrastructure and systems within the national space economy.

The transport services and infrastructure provided in 2010 must thus meet the requirements of efficiency, safety, quality and cost-effectiveness in the growth and development of the South African economy within the goals and objectives of the accelerated growth initiative (ASGISA). The services and infrastructure developed must be accessible to visitors and citizens alike within South Africa. Transport forms the 'lifeblood' of the development of any spatial system and is thus the key driver in economic and spatial growth and development.

The present transport system, infrastructure and services in South Africa are already under enormous pressure due to rapidly increasing urbanization following democratization in 1994. The development of transport infrastructure and services for the World Cup 2010 thus serves as an important incentive to address existing needs and unlock further development potential.

This paper analyzes the transport planning undertaken in South Africa based on an assessment of the impact of the event and its role to support and facilitate development in the period after 2010. The recent initiative to prepare a National Transport Master Plan for 2050 (NATMAP) for South Africa will be used as the basis on which to assess the value and contribution of the transportation planning projects presently being implemented.
\end{abstract}

Keywords: transport planning, transport infrastructure, Soccer World Cup. 


\section{Introduction}

Transport and spatial planning in South Africa prior to 1994 focused on the policy of separate development and service provision based on racial segregation. Situma [1] states that whilst there is a perception that the people's Government of South Africa in 1994 inherited the best transportation systems in Africa, the realities (especially in the former homelands areas) indicate extreme disparities between the former RSA white man's enclaves and areas predominantly occupied by historically disadvantaged individuals. The current government also inadvertently inherited irritating transportation planning, management, and operational problems.

The existing rail infrastructure, bus transport and road infrastructure clearly shows signs of capacity problems and ageing characteristics that inhibits transport service delivery and economic growth. At the same time South Africa will be hosting the Soccer World Cup in 2010 and ad hoc upgrading of certain modes of transport and related infrastructure is being implemented.

In the light of the above mentioned, the development of transport planning after 15 years of democracy will be assessed whilst the preparedness and readiness of transport planning to support growth and development in general and the Soccer World Cup 2010 will be reported on.

The initiative by the National Department of Transport (NDOT, 2006) to develop a National Transport Master Plan (NATMAP) [10] for 2050 and the National Spatial Development Perspective (NSDP, 2007) will be taken as points of departure to analyze the position as described above.

\section{Policy and legislative framework guiding transport planning}

\subsection{National sphere of government}

Transport planning (land transport) and spatial planning and development in South Africa on national level is being guided through the policy and legislative framework as included in Table 1.

As far as the policy and legislative framework is concerned, Situma [1] concludes that 'Pre and post 1994 transportation policies are best described as cumbersome and counterproductive. The pre 1994 legislations simply favoured the white population and provided sub standard planning controls in the former homelands. The post 1994 legislations and policies are over ambitious and unrealistic. For example it is not easy to explain why the National Land Transport Transition Act 2000, which took so long to prepare, was then promulgated in 2000 without some sections. This is probably the most complicated and resources wasting aspect of the transportation planning process'.

Since 1994 with democratization, the two policy documents that are of significance included the White Paper on National Transport Policy (1996) [2] and the Moving South Africa (Vision 2020) (MSA) (1999) [3] as published by 
the Department of Transport. These documents endeavoured to address some of the transport and spatial implications and deficiencies inherited by the democratic government.

The MSA included a vision for transport in 2020; foundations for a transport strategy; urban and rural passenger transport; tourists and long distance customers; special needs customers; freight transport; recommendations on integrating the strategic framework and a way forward. For the first time in the history of South Africa, the government has developed a framework which integrates all parts of transport into a common vision and plan for action.

Table 1: $\quad$ Policy and legislative framework guiding transport planning.

\begin{tabular}{|c|c|}
\hline Policy framework & Legislative framework \\
\hline $\begin{array}{l}\text { White Paper on National Transport Policy (1996) } \\
\text { [2] }\end{array}$ & Urban Transport Act (Act 78 of 1977) [14] \\
\hline 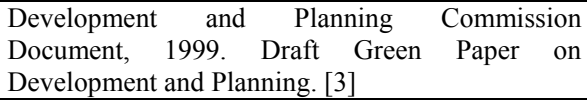 & Road Transport Act (Act 74 of 1977) [15] \\
\hline Moving South Africa (Vision 2020) (1999) [4] & $\begin{array}{l}\text { Development Facilitation Act (Act } 67 \text { of } \\
\text { 1995) [16] }\end{array}$ \\
\hline $\begin{array}{l}\text { White Paper on Spatial Planning and Land Use } \\
\text { Management (2001) [5] }\end{array}$ & $\begin{array}{l}\text { National Road Traffic Act (Act } 93 \text { of } \\
\text { 1996) [17] }\end{array}$ \\
\hline $\begin{array}{l}\text { National Spatial Development Perspective (2003) } \\
\text { [6] }\end{array}$ & $\begin{array}{l}\text { Constitution of the Republic of South } \\
\text { Africa (Act } 108 \text { of 1996) [18] }\end{array}$ \\
\hline $\begin{array}{l}\text { Rural Transport Strategy for South Africa (2003) } \\
\text { [7] }\end{array}$ & $\begin{array}{l}\text { National Transport Interim Arrangements } \\
\text { Act (Act } 45 \text { of 1998) [19] }\end{array}$ \\
\hline $\begin{array}{l}\text { National Spatial Development Perspective (2006) } \\
\text { [8] }\end{array}$ & $\begin{array}{l}\text { Cross Border Road Transport Act (Act } 4 \text { of } \\
\text { 1998) } \\
{[20]}\end{array}$ \\
\hline Housing Atlas (2005) [9] & $\begin{array}{l}\text { Transport Appeal Tribunal Act (Act } 39 \text { of } \\
\text { 1998) [21] }\end{array}$ \\
\hline $\begin{array}{l}\text { National Transport Master Plan } 2050 \text { (NATMAP } \\
\text { 2050) (2006) (in process of formulation) [10] }\end{array}$ & Road Traffic Act (Act 29 of 1989) [22] \\
\hline $\begin{array}{l}\text { Accelerated and Shared Growth-South Africa } \\
\text { (ASGISA) (2006) [11] }\end{array}$ & $\begin{array}{l}\text { Municipal Structures Act (Act } 117 \text { of } \\
\text { 1998) [23] }\end{array}$ \\
\hline $\begin{array}{l}\text { Draft minimum requirements for the preparation of } \\
\text { integrated transport plans (ITP) (2007) [12] }\end{array}$ & $\begin{array}{l}\text { National Land Transport Transition Act } \\
(\text { Act } 22 \text { of 2000) [24] }\end{array}$ \\
\hline $\begin{array}{l}\text { National Land Transport Strategic } \text { Framework } \\
(2006-2011)(2002) \text { (Draft) [13] }\end{array}$ & $\begin{array}{l}\text { Municipal Systems Act, (Act } 32 \text { of 2000) } \\
\text { [25] }\end{array}$ \\
\hline
\end{tabular}

Source: Own construction.

Krynauw and Cameron [26] states that MSA, (1999) [4] which set out the strategic vision for transport for 2020, took the strategic targets of the White Paper further and suggested strategies which could be used to achieve them. The outcome of the White Paper and MSA has been incorporated into legislation (NLTTA, 2000) [24] intended to implement the transport policies and strategies. The NLTTA (2000) includes provisions for monitoring the performance of the public transport system and measuring performance in respect of key performance indicators (KPIs). 


\subsection{Provincial sphere of government}

For the purposes of this paper, it should be noted that within the provincial sphere of government further local policy and legislative frameworks applies. The context thereof normally consists of legislation guiding provincial land transport planning; provincial growth and development strategies (PGDS); provincial spatial development frameworks (PSDF); provincial land transport frameworks (LTPF) and environmental policies and strategies.

\subsection{Local or municipal sphere of government}

Similar instruments guiding transport and spatial planning and development exist within the third sphere of government including integrated development plans (IDP); spatial development frameworks (SDF); integrated transport plans (ITP); environmental management frameworks (EMF) and strategic environmental assessments (SEA).

As far as transport planning for Soccer World Cup 2010 is concerned all three spheres of government will be involved. However, the role of national sphere of government will form the focus of this paper. Stapelberg [27] discussed the role of transport planning in the quest for sustainable land use. He concluded that the aim is to have cities, communities, and planning and development that can be sustainable and in the process to have effective transport systems. 'It is clear that the legislation available requires it and that the means and mechanisms are in place'.

\section{Transport planning for Soccer World Cup 2010}

\subsection{Approach towards transport planning}

Transport planning and development in terms of the strategy and objectives as included in the policy and legislative framework (Table 1) within the national spatial system took place over the past 15 years within the budgetary system of the Department of Finance. In addition to this strategic and programmed approach, transport development needs for the World Rugby Cup (1995) and the Cricket World Cup (2003) resulted in additional investment in transport infrastructure, management and operations to support the events. It also contributed to the development of tourism.

The National Department of Transport in 2008 [28] gave a perspective of the state of the South African transport system. The Department states in an address to the SAICE Transportation Quadrennial that roads, rail, ports and aviation infrastructure are arteries that guide transport modes in transporting people and goods from various places for various socio-economic developments. The Department (2008) [28] in line with the provisions of the transport planning and legislative framework reiterated that transport plays a significant role in attaining the objectives in transforming the well-being of the citizens and that it is addressed in a manner that benefits all. 
Of importance to this paper is the Departments statement that 'Long after the 2010 FIFA World Cup, our transport systems should be able to sustain our economy. The investments we are making in transport services and infrastructure should benefit the rest of the country. The 2010 World Cup is a catalyst on the country's infrastructure and social development projects that will benefit all South Africans long after the tournament is forgotten'

Investment in transport is also set to achieve the Millennium Development Goals (MDG) [29] and the Accelerated Shared Growth Initiative of South Africa (ASGISA) (2006) [11].

\subsection{Transportation planning by host cities for Soccer World Cup 2010}

The Department of Transport (DOT), (2008) [10] states that the Soccer World Cup 2010 will be a success if the accelerated transport investments secured in preparation for the event yield a lasting legacy of quality transport services, infrastructure and systems. The legacy is actually twofold:

- The services resulting from the approach implemented for the event itself.

- The impression that the remainder of the World will be left with after the event.

The NDOT [10] states that the transport services and infrastructure provided in 2010 must thus meet the efficiency, safety, quality and cost-effective requirements of the modern era, and must be accessible to all, visitors and residents alike. As transport will be one of the key factors on which visitors will judge the success of the event it is essential that it leaves a lasting positive impression on all users. The transport planning for 2010 must thus provide an affordable service to both visitors and residents at the level of service appropriate to their status and the mode used.

The approach towards transport planning and implementation for Soccer World Cup 2010 is contained in various planning and strategy documents of the NDOT including the following: Transport Action Plan for 2010 [30]; Initial Transport Operational Plan for the FIFA World Cup [31] and the National Transport Master Plan [10].

The NDOT released a study, the 'Initial Transport Operational Plan (INTOP) for the 2010 FIFA World Cup' [31] during February 2008. This document provides some guidance to the host cities of the 2010 FIFA World Cup to assist in the development of their Transport Operational Plans (TOPs) for the event. It provides a broad framework from which TOPs can be developed.

However, the guidelines provided in the framework are complicated by the fact that all 3 spheres of government are responsible for different elements of the TOPs. It is therefore impossible for any city to develop a TOP without major involvement of the relevant provinces and the NDOT, as agent of the Local Organizing Committee (LOC) of the 2010 FIFA World Cup.

In order for a city to develop a TOP some basic guiding information is required in the case of each of the host cities. This includes the location of the main and supporting event venues and related infrastructure; the training venues, 
official FIFA Fan Parks, other city fan festivals or viewing sites and a 2010 accommodation plan for each host city. Most of the host cities initially did not have access to some of the data and information required to compile the Transport Operational Plans (TOPs) due to capacity problems. Since 1997 most of the host cities have formulated detailed draft TOPs to support the event. It includes plans for the following host cities:

- Polokwane Host City

- City of Cape Town

- Western Cape Provincial Transport Operations Plan

- Mombela Host City

- Nelson Mandela Bay Municipal host City

- Mangaung Host City

- City of Tshwane Host City

- Rustenburg Host City

- Ethekwini Host City

- City of Johannesburg Host City

The host city plans are supported by national modal plans inclusive of bus operations including a rail operations plans. The transportation planning and strategy is being coordinated by the 2010 Transport Task Team (LTTT) and the 2010 Host City Transport Task Team (HCTTT).

\subsection{Overview of transportation planning projects in support of Soccer World Cup 2010}

The National Department of Transport in 2008 [28] gave a perspective of the state of the South African transport system. In this overview the role of Soccer World Cup 2010 as the central catalyst for transportation planning and infrastructure development is evident. Transportation related infrastructure guides the development of transport modes, movement of goods to and from various places and in support of various socio-economic and infrastructure developments.

Table 2 gives an overview of the capital spending on transport related infrastructure, management and operations supporting Soccer World Cup 2010 as envisaged in 2008 by the NDOT [28]. From Table 2 it is evident that some R690.30 billion ( $€ 55.23$ billion) will be invested in transport and related infrastructure in support of the Soccer World Cup 2010. This excludes other direct and indirect investment in transport by provinces and municipalities in support of the event.

The South African Government views the Soccer World Cup 2010 as a major catalyst (Table 2) in the renewal and creation of new transport related infrastructure and services. The new infrastructure will form the backbone of all socio-economic development in the period after 2010. As can be deduced from Table 2 it illustrates that investment will be taking place across all transport modes with the exception of harbours and maritime infrastructure.

The transport related projects is also important if the development and priority of tourism is considered. In terms of ASGISA (2006) [11] the tourism 
sector has already grown rapidly in South Africa but is ready for a second phase of growth that could take its contribution to GDP from about $8 \%$ to about $12 \%$, and increase employment by up to 400000 job opportunities. In the realization of this goal and objective the availability of an effective and efficient transport system is of core importance. The Soccer World Cup 2010 will thus be an important contributor in realizing this objective.

Table 2: $\quad$ Investment capital in transport and related infrastructure (2008).

\begin{tabular}{|c|c|c|}
\hline Investment (R) & Project/programme & Sector and benefit \\
\hline R500 billion ( $€ 40$ billion) & $\begin{array}{l}\text { Integrated public sector } \\
\text { infrastructure investment } \\
\text { programme. Promotion } \\
\text { of existing Government } \\
\text { Programmes }\end{array}$ & $\begin{array}{l}\text { National, provincial and local sphere } \\
\text { of government. Private sector } \\
\text { contractors. Job creation for } \\
\text { community. Tourism enhancement }\end{array}$ \\
\hline R9.6 billion ( $€ 0.77$ billion) & $\begin{array}{l}\text { Construction of stadiums } \\
\text { for } 2010\end{array}$ & $\begin{array}{l}\text { Local municipalities and Private } \\
\text { sector. Job creation and enhancement } \\
\text { of skills development }\end{array}$ \\
\hline R20.0 billion ( $€ 1.6$ billion) & $\begin{array}{l}\text { Airport development } \\
\text { (next } 5 \text { years) }\end{array}$ & $\begin{array}{l}\text { Private sector, job creation, tourism } \\
\text { enhancement }\end{array}$ \\
\hline R400 million (€32 million) & $\begin{array}{l}\text { Air traffic navigation } \\
\text { systems }\end{array}$ & $\begin{array}{l}\text { Private sector and development of the } \\
\text { aviation industry }\end{array}$ \\
\hline R7.7 billion ( $€ 0.62$ billion) & $\begin{array}{l}\text { Taxi Recapitalization } \\
\text { Programme }\end{array}$ & $\begin{array}{l}\text { Taxi industry, passengers, tourism } \\
\text { sector development, job creation }\end{array}$ \\
\hline R70 billion ( $€ 5.6$ billion) & $\begin{array}{l}\text { Preservation } r \text { and } \\
\text { upgrading of road } \\
\text { network infrastructure }\end{array}$ & $\begin{array}{l}\text { Private sector, road users, passengers, } \\
\text { community, traffic safety, job creation } \\
\text { and skills development and tourism } \\
\text { enhancement }\end{array}$ \\
\hline R3 billion ( $€ 0.24$ billion) & $\begin{array}{lr}\text { Access } & \text { road } \\
\text { improvement } & \text { under the } \\
\text { Extended } & \text { Works } \\
\text { Programme } & \\
\end{array}$ & $\begin{array}{l}\text { Private sector, public sector, road } \\
\text { users, traffic safety, job creation and } \\
\text { skills development, urban and rural } \\
\text { integration }\end{array}$ \\
\hline R23 billion ( $€ 1.84$ billion) & $\begin{array}{l}\text { Gauteng } \quad \text { Freeway } \\
\text { Improvement Scheme }\end{array}$ & $\begin{array}{l}\text { Private sector, public sector, road } \\
\text { users, job creation and skills } \\
\text { development, improvement of } \\
\text { accessibility, traffic safety, saving on } \\
\text { travelling time due to decrease in } \\
\text { traffic congestion }\end{array}$ \\
\hline R25 billion ( $€ 2.0$ billion) & $\begin{array}{l}\text { Gautrain } \quad \text { Rail Link } \\
\text { Project }\end{array}$ & $\begin{array}{l}\text { Private sector, public sector, public } \\
\text { transport passengers, improvement of } \\
\text { modal choice, job creation, reduction } \\
\text { in travelling time, improved traffic } \\
\text { safety, tourism promotion }\end{array}$ \\
\hline R18 billion ( $€ 1.44$ billion) & $\begin{array}{l}\text { Improvement of the } \\
\text { passenger rail system } \\
\text { over the next } 4 \text { years }\end{array}$ & $\begin{array}{l}\text { Private sector, public sector, public } \\
\text { transport passengers, job creation, less } \\
\text { travelling time, job creation, improved } \\
\text { modal choice, tourism promotion }\end{array}$ \\
\hline R13.6 billion (€1.09) & $\begin{array}{l}\text { Improvement of public } \\
\text { transport infrastructure } \\
\text { for } 2010\end{array}$ & $\begin{array}{l}\text { Private sector, public sector, public } \\
\text { transport passengers, job creation, less } \\
\text { travelling time, job creation, improved } \\
\text { modal choice, tourism promotion }\end{array}$ \\
\hline
\end{tabular}

Source: Own construction from NDOT, 2008 [28]. 


\section{The national transport master plan 2050 and the Soccer World Cup 2010}

The development of transport planning in South Africa since 1994 was dominated by the fragmented spatial system that was inherited by the Government from previous political dispensations. Some of the challenges and problems in order to promote sustainable transport thus relates to the political, social and economic forces that founded the fragmented spatial systems that still exists in 2009 and that impacts of the Soccer World Cup 2010 transportation planning.

In 2005 the South African Government gave a directive to the National Department of Transport (NDOT) to prepare an integrated transport infrastructure plan for the national spatial system. In the light of the factors as described above the NDOT proposed that a land use/multi-modal transport systems framework be prepared. It was consequently, after a process of consultation, decided to embark on the preparation on a National Transport Master Plan with the horizon-year of 2050 (NDOT, 2006) [10]. This plan for transport will guide planning, implementation, operations and management for all modes of transport within all three spheres of government.

It should, however, be noted that the focus of NATMAP 2050 will be limited to macro scale. Local developmental, spatial and transport planning will be through the level of IDPs [25] and ITPs [24]. The NATMAP 2050 [10] project will thus not provide solutions the spatial and transport planning problems within urban areas although the Soccer World Cup 2010 is in nature predominantly urban orientated. Solutions to overcome the spatial deficiencies of urban areas will have to be formulated on local level. NATMAP 2050 [10] should however optimize integration of connectivity through a multi-modal approach within the national spatial system as contained in the various Transport Operation Plans (TOPs) [31] of the Host Cities for Soccer World Cup 2010.

The NATMAP 2050 [10] project is being carried out on a provincial spatial system basis within which the goals and objectives are being addressed with special reference to compile a macro sustainable transport plan. The NATMAP 2050 process consists of four phases. Phase 1 has been completed in 2008 whilst the other phases will follow in 2009. It is expected that the project will be published in 2010. The success of NATMAP 2050 as an integration mechanism can only be assessed once the products as described in the terms of reference are available and subject to specialist scrutiny and evaluation. However, NATMAP 2050 pivots on the impact of sustainable transport planning underpinning Soccer World Cup 2010.

\section{Conclusions}

From the research the following general conclusion can be deduced:

- The fragmented spatial system in South Africa that has been inherited by the democratic government poses specific challenges in the transportation planning and project implementation for the Soccer World Cup 2010. 
- Since democratization in 1994 South Africa has experience a period of relative economic growth and development that has been structured in a formalized strategy as to ensure optimal growth and development.

- During period 1994 to 2008 the transportation scene has been characterized by a gradual decline in the state of land transport infrastructure notwithstanding annual ad hoc investments by all spheres of government and Transnet.

- $\quad$ Soccer World Cup 2010 serves as the major catalyst in the renewal of transport infrastructure and services. The investment of some $€ 55.23$ billion directs this major incentive to ensure that transport planning and development is taken to a higher level of infrastructure and service delivery.

- The impact of the investment will initially favour the urban and metropolitan orientated spatial systems. The NATMAP 2050 project will ensure that transportation planning and related infrastructure in terms of improved connectivity and integration between urban and rural components of the spatial system will be addressed.

- Sustainable transport planning, infrastructure development and improved service delivery will remain a function of the ability of Government to facilitate ongoing growth and development (ASGISA) in terms of physical and spatial restructuring.

\section{References}

[1] Annual South African Transport Conference, 2002: Situma, L 2002. 'Challenges of transport and spatial development in the Eastern Cape'. Proceedings of the 21 st ASATC. University of Pretoria. Pretoria.

[2] Department of Transport, 1996: White Paper on National Transport Policy. Government Printer. Pretoria.

[3] Development and Planning Commission Document, 1999. Draft Green Paper on Development and Planning. Government Printer. Pretoria.

[4] Department of Transport, 1999: Moving South Africa-The Action Agenda. Departmental publication. Pretoria.

[5] Department of Agriculture and Land Affairs, 2001. White Paper on Spatial Planning and Land Use Management. Government Printer. Pretoria

[6] The Presidency, 2003: National Spatial Development Perspective. Published by The Presidency. RSA.

[7] Department of Transport, 2003: Rural Transport Strategy for South Africa. Departmental publication. Pretoria.

[8] The Presidency, 2006: National Spatial Development Perspective. Published by The Presidency. RSA.

[9] Department of Housing, 2005: The Housing Atlas 2005 Document. National Housing Investment Potential Atlas. NDH and CSIR. Pretoria. South Africa.

[10] Department of Transport, 2006: National Transport Master Plan. Natmap 2050. Background Document. Website: http://www.transport.gov.za 
[11] Government of South Africa, 2006: Background document: A Catalyst for Accelerated and Shared Growth in South Africa. Media briefing by the Deputy President Phumzile Mlambo-Ngcuka, 6 February, 2006. Pretoria.

[12] Department of Transport, 2007: National Land Transport Transition Act (Act 22 of 2000). Integrated Transport Plans: Minimum requirements for the preparation of integrated transport plans. Government Gazette 30506, Notices R.1119 and R.1120. Government Printer. Pretoria.

[13] Department of Transport, 2002: National Land Transport Strategic Framework (2006-2011) (2002) (Draft). Departmental publication. Pretoria.

[14] Government, Department of Transport, 1977: Urban Transport Act (Act 78 of 1977). Government Printer. Pretoria.

[15] Government, Department of Transport, 1974: Road Transport Act (Act 74 of 1977). Government Printer. Pretoria.

[16] Government, Department of Transport, 1989: Road Traffic Act (Act 29 of 1989). Government Printer. Pretoria.

[17] Government, Office of the President, 1995: Development Facilitation Act (Act 67 of 1995). Government Printer. Pretoria.

[18] Government, Constitutional Court, 1996: Constitution of the Republic of South Africa (Act 108 of 1996).

[19] Government, Department of Transport, 1998: National Transport Interim Arrangements Act (Act 45 of 1998). Government Printer. Pretoria.

[20] Government, Department of Transport, 1998: Cross Border Road Transport Act (Act 4 of 1998). Government Printer. Pretoria.

[21] Government, Department of Transport, 1998: Transport Appeal Tribunal Act (At 39 of 1998). Government Printer. Pretoria.

[22] Government, Department of Transport, 1989: Road Traffic Act (Act 29 of 1989). Government Printer. Pretoria.

[23] Government, Local Government, 1998: Municipal Structures Act (Act 117 of 1998). Government Printer. Pretoria.

[24] Department of Transport, 2000: National Land Transport Transition Act (Act 22 of 2002). Government Printer. Pretoria.

[25] Government, Local Government, 2000: Municipal Systems Act (Act 32 of 2000). Government Printer. Pretoria.

[26] Annual South African Transport Conference, 2003: Krynauw, M.N. and Cameron, J.W.M. 'National land transport key performance indicators (KPIs) as a measurement of sustainable transport: are we measuring the right things?' Proceedings of the 22nd ASATC. University of Pretoria. Pretoria.

[27] Annual South African Transport Conference, 2006: Stapelberg, H. 'The role of transport planning in the quest for sustainable land use'. Proceedings of the 25th ASATC. University of Pretoria. Pretoria.

[28] Department of Transport, 2008; Gamo, L. Address at the SAICE Transport Quadrennial (25 September, 2008). 'Transport Delivery beyond 2010'. Website: http//www.transport.gov.za/comm-centre/sp/2008/sp0925.html

[29] United Nations, 2005: Millennium Development Goals for South Africa. Johannesburg 
[30] National Department of Transport, 2006: Transport Action Plan for 2010. Departmental publication. Pretoria.

[31] National Department of Transport, 2008: Initial Transport Operational Plan for the 2010 FIFA World Cup (INTOP Report). Departmental publication. Pretoria. 